\title{
CROSSBREEDING EXOTIC AND LOCAL BREEDS OF RABBITS IN CAMEROON: BREED OF SIRE AND BREED OF DAM EFFECTS
}

\author{
L. N. Nwakalor' and M. Ngo Ndjon \\ Deparment of Animal Science. \\ University of Nigeria, Nsukku, Nigeria
}

\begin{abstract}
Data on 142 offspring from $11+$ litters produced in a reciprocal crossbreceding prongramme involving local (LOC). New Zealand White (NZW) and (alifornian (CL) rabbits al the Insfirme'

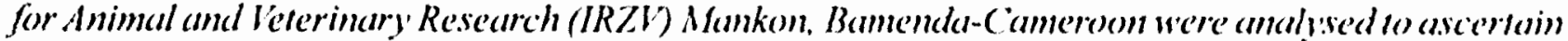
the paternal and maternal breed effects on preweaning litter ardits and individent weaning weight using least-squares analysis of covariance. Breed of sire significamly $\left(P^{3}<0.05\right)$ influened ed individual weaning weight (lWh') but not litter birth number (LBN) amd litler sizes at birth (LSB). all 28 dens

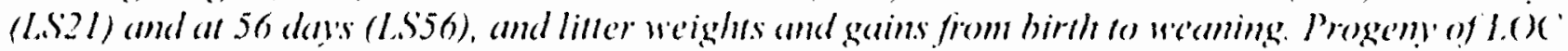

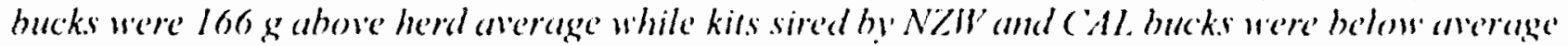
in IIVW. Least-squares constants showed significant $(P<0.05)$ effects of bred of dam on LBN. litfer

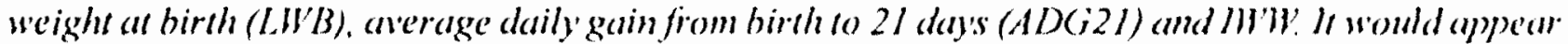
shat LOC' dams had good prolificacy hat poor mothering ability while NZIt dams showed good prolificacy, mothering ability and growth potentals in their litters. Evidence also showed what (Al.

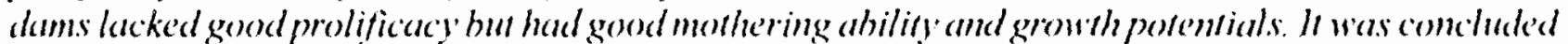

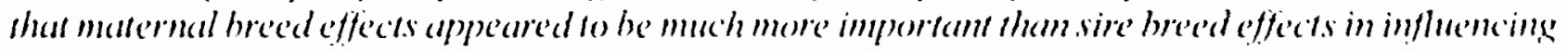
prewerning litter characters of the rabhits.
\end{abstract}

Key words: Breed, sire, dam, crossbrecding, rabbits.

\section{INTRODUCTION}

When heterosis is achieved in a crossbred population, the contribution of the males and females of a particular breed may be of interest. Knowledge of paternal and maternal breed eflects, which are direct genetic but non-additive (dominance. epistasis) effects of paremtal genes on the performance of their offspring, is needed for designing brecding plans with respect to which breed of sire to mate with females of a particular breed or which breed of female to cross with different sire breeds in order to achieve optimum results. A desirable sire breed could pass on to its crossbred progeny genes such as those governing fast growth and high sexual urge. while a desirable dam breed could transfer high prolificacy and good mothering ability to her oftspring.

There is a dearth of information on breed of sire and breed of dam effects in heterotic studies conducted on crossbred populations of exotic breeds of rabbits and worse still between exotic and local breeds of rabbits. Nevertleless. Rouvier (1981) in France found Burgundy lawn and Califomian sires, as well as New /caland White dams the best in a rabbit multibreed comparison of heterotic effects on litter characters. Other studies (Niedzwiadek. 1979: Rouvier, 1980; Lukefahr er al. 198.36) have also established the superiority of N\%W does over CAL does in prolificacy. I ukctahr e' al. (1983a) showed that maternal breed effects appear to be mucl more important than sire breed effects in influencing litter characters while the stubly of Partridge et al. (1981) on breed differences for maternal and preweaning litter traits has demonstrated the potential role of utilizing existing breed resources to maximize bioconomic returns to the commercial rabbit 
enterprise. This study was undertaken to investigate the maternal and paternal breed effects on litter characters and individual weaning weight in reciprocal crossbreeding among local. New \%ealand White and Californian rabbits.

\section{MATERIALS AND METHODS}

\section{Source of data}

The rabbit breeding project at the Institute for Animal and Veterinary Research (IRZV) Mankon. Bamenda-Cameroon provided data for the study. The data were collected on 442 oflspring from 114 litters obtained from a reciprocal crossbreeding programme involving in all 24 bucks and 67 does of the local (I.OC). New Zealand White (NZW) and Californian ( $\mathrm{C} A \mathrm{~L}$ ) breeds of rabbits. Tivo major scasons are recognized in the area: a 5 -month dry season (mid-()etober to mid-March) and a 7 -month rainy season (mid-March to mid-Oclober). The ambient temperatures average $21^{\circ} \mathrm{C}$ but fluctuate a lot during the dry season when a maximum of $31.6^{\circ} \mathrm{C}$ and minimum of $6.3^{\circ} \mathrm{C}$ are sometimes recorded. Humidity in general is high and reaches a peak of $87 \%$ during the rainy season. with a minimum of $53 \%$ during the dry season.

\section{Breeds and animal management}

The crossbreeding programme involved the Local (LOC). New Zealand White (NZW) and Californian ( $\mathrm{C} A \mathrm{~L}$ ) breeds in two-way reciprocal matings. The term reciprocal matings refers to the two variants of (genetically) the same cross which though, on average are genetically alike. difler because the wo reciprocal crosses have had a different maternal enviromment. The reciprocal crosses were: NZW $\times$ L.OC (main cross), IOC $\times$ NZW (reciprocal); CAL $\times I . O C^{\circ}$ (main cross), I.OC $\times$ (AL (reciprocal); and N/W $x(A L$ (main cross), CAL $\times N Z W$ (reciprocal). The maternal influences can be important for the oftspring at the time of birth and perhaps, up to the time of weaning. Similarly, the influence of the sire breed can be ascertained from this mating scheme. The animals were bred early in the morning and following a successful mating, pregnancy diagnosis was done by palpation of the lower abdomen 10 days later. Does found empty were re-mated with the corresponding buck. After kindling. litters were evaluated on weckly basis till weaning at 8 weeks when individual weaning weights and sex were recorded. The rabbits were fed a concentrate ration with $18.6 \%$ crude prolein and $2400 \mathrm{kcal}$ $\mathrm{ME} / \mathrm{kg}$ body weight given frec choice and about $100 \mathrm{~g}$ of fresh herbage. liresh clean water was provided freely.

\section{Characters studied}

The traits studied were live birth number (I.J3N), litter size at birth (L.SB), litter size at 21 days (I.S21) and at 56 days (1.S56). litter weight at birth (LWB), at 21 days (1.W/21) and at 56 days (I.W56), average daily growth rate from birth to 21 days $(A D)(321)$, average daily growth rate from 21 to 56 days $(\triangle D(556)$ and individual weaning weight (IWW).

where:

$A D(321=(L W 21-L W 13) / \mid 21 \times 1 . \$ 21]$

ADG56 $=($ LW56-1.W21)/ $(56-21) \times 1.5 .56 \mid$

These traits were recorded for each litter or individual (in the case of IWW) from a cross involving a parlicular breed of sire and a particular brecd of dam.

\section{Statistical analyses}

The data were analyzed by least-squares analysis of covariance as described by Harvey (1990). Corrections were made to the data for important environmental effects, namely fixed eflect of season of birth of the litter. fixed effect of sex of rabbit (for IWW doe and weight of doe at kindling through heir inclusion in the models as covariates. in order to remove any biases due to these lactors. In the initial analysis breed of sire $x$ breed of dam. breed of sire $x$ season of birth and breed of dam $x$ season of birth interactions were included in the models. Since these interaction effects were found to be nonsignilicant for most of the traits. they were dropped from the linal models. Thus. the wo lixed eflects models litted are as follows:

For litter traits:

$$
Y_{1, k 1}=\mu+\Lambda_{1}+B_{1}+S_{h}+b_{1}(G-\bar{G})+
$$




$$
b_{2}(W-W)+c_{1, k 1}
$$

lior individual weaning weight:

$$
\begin{aligned}
Y_{1, k \mathrm{kn}}= & \mu+A_{1}+B_{1}+S_{k}+X_{1}+b_{3}(G-\bar{G}) \\
& +b_{1}(W-\bar{W})+c_{1, k / m}
\end{aligned}
$$

where:

$$
Y_{n k l m}\left(Y_{1, k 1}\right)=\text { a single observation on a rabbit }
$$

$$
\text { (litter) }
$$

$\mu=$ overall mean

$\Lambda=$ fixed effect of the $i^{\text {th }}$ breed of sire

$$
(i=1,2,3)
$$

$B=$ fixed effect of the $j^{\text {th }}$ breed of dam

$$
(j=1,2,3)
$$

$S_{k}=$ fixed effect of the $k^{\text {th }}$ season of birth of the litter (dry vs rainy)

$x_{1}=$ fixed effect of the $1^{\text {th }}$ sex of rabbit (male vs female)

G = age of doe at kindling in days

$\mathrm{W}=$ weight of doc at kindling in $\mathrm{kg}$

$b_{1}$ and $b_{3}=$ partial linear regression coeflicients of a trait on (i

$\mathrm{b}_{2}$ and $\mathrm{b}_{1}=$ partial linear regression coeflicients of a trait on $\mathrm{W}$

$\mathrm{e}_{1, k / \mathrm{m}}\left(\mathrm{c}_{1, k)}\right)=$ the random residual effect associated with the variable $Y$ $\left(Y_{1, \mathrm{~h} h}\right)$ assumed to be identically, independently and normally distributed with zero mean and constant unit variance, i.c. e $e_{1, \mathrm{k} / \mathrm{m}}\left(\mathrm{c}_{1, \mathrm{kN}}\right)$

$$
\sim \operatorname{iind}\left(0, \dot{\sigma}^{2}\right)
$$

Least-squares constants for breed of sire and breed of dam derived from the amalysis were used in quantifying the contribution af each parent breed in the performance of dillerent traits.

\section{RESULTS AND DISCUSSION}

\section{Breed of sire}

l.cast-squares constants for brecd of sire for reproduction traits are shown in rable 1. Least-squares means were 6.37 for I.BN. 6.51 for LSB, 5.40 for $1 . S 21$ and 5.06 for I.S56. There were no signilicant differences $(P>0.05)$ between breeds of sire in these traits. However, 1.OC bucks tended to have litters with the poorest performance in early preweaning characters (1.BN, LSB and LS21). Litters from NZW sires were intermediate in birth traits (L.BN and I.SB). A 21 and 56 days litters sired by NZW bucks were the most numerous although the differences among breeds were not significant $(P>0.05)$. There was also a tendency for CAL sires to excel in L.BSN and LSB.

Breed of sire effect was nonsignificant (P>0.05) for litter traits involving weights and gains but differed $(P<0.05)$ for IWW (lable 2$)$. litters from IOC bucks had the highest $1 \mathrm{~W} / \mathrm{W}$ ( $166 \mathrm{~g}$ above herd average). indicating the good growth potential inherent in sires of the breed. NT.W and CAl. sires were below average in influencing IWW.

Previous results with respect to number weaned (Rouvier. 1973) and weaning weights (Carregal, 1980) agree with the present lindings in demonstrating minor diflerences attributable to $N Z W$ vs $C A L$. sires. The ranking of $N Z W$ and CAl. sires on their influence on weaning weight from the present study agrees with the report of Rouvier (1980). The present results also agree with Lukefahr et al. (1983a) who reported small differences for all traits studied except percentage early survival of litlers, in a New /caland WhiteCaliformian sire breed contrast. In particular. nome of the sire breeds was outstanding in influencing reproductive (prolificacy) characteristics. 
Table 1. Least-squares constants ${ }^{1}$ for brecd of sire $^{2}$ for reproduction traits $^{3}$

\begin{tabular}{llllllll}
\hline & No. & obs. & LBN & LSB & L.S21 & No. obs. & LS56 \\
Total/overall mean & 114 & 6.37 & 6.51 & 5.40 & 104 & 5.06 \\
L.OC & 48 & -0.47 & -0.51 & -0.49 & 47 & -0.09 \\
NZW & 44 & -0.25 & 0.10 & 0.43 & 37 & 0.52 \\
CAL & 22 & 0.72 & 0.41 & 0.06 & 20 & -0.43
\end{tabular}

There were no significant differences between breeds of sire $(\mathrm{P}>0.05)$.

${ }^{2} 1 . \mathrm{OC}=$ Local, NZW $=$ New Zealand White, CAL $=$ Californian.

'I.BN - live birth number, LSB = Litter size at birth, $1 . S 21$ (L.S.56) - Litter size at 21 days (56 days).

Table 2. Least-squares constants for brecd of sire ${ }^{1}$ for production traits ${ }^{2}$

\begin{tabular}{lllllllllllll} 
& $\begin{array}{l}\text { No. } \\
\text { obs. }\end{array}$ & LW13 & L.W21 & $\begin{array}{l}\text { No. } \\
(\mathrm{kg})\end{array}$ & $\begin{array}{l}\text { obs. } \\
(\mathrm{kg})\end{array}$ & $\begin{array}{l}\text { No. } \\
\text { obs. }\end{array}$ & $\begin{array}{l}A D(\mathrm{~g}) \\
(\mathrm{g} / \mathrm{d})\end{array}$ & $\begin{array}{l}\text { No. } \\
\text { obs. }\end{array}$ & $\begin{array}{l}\text { ADG56 } \\
(\mathrm{g} / \mathrm{d})\end{array}$ & $\begin{array}{l}\text { No. } \\
\text { obs. }\end{array}$ & $\begin{array}{l}\text { IWW } \\
(\mathrm{g})\end{array}$ \\
$\begin{array}{l}\text { Overall } \\
\text { mean }\end{array}$ & 114 & 0.354 & 1.210 & 97 & 3.839 & 112 & 7.9 & 94 & 15.8 & 442 & 755 \\
LOC & 48 & -0.061 & -0.085 & 44 & 0.270 & 47 & 2.5 & 43 & -1.7 & 213 & $166^{\circ}$ \\
NZW & 4.4 & 0.027 & 0.169 & 33 & 0.413 & 4.4 & 1.7 & 33 & -1.8 & 1.47 & $-4^{\prime \prime}$ \\
CAL & 22 & 0.034 & -0.084 & 20 & -0.713 & 21 & -4.2 & 18 & 3.5 & 82 & $-162^{\circ}$ \\
\hline
\end{tabular}

ath Constants within columns with different superscripts are significantly $(P<0.05)$ different.

'Refer to Table I.

'LWB = I.itter weight at birth, LW2I (LW56) - Litter weight at 21 days (at 56 days), ADG21 - Average daily growth rate from birth to 21 days, ADG56 - Average growth rate from 21056 days. IWW Individual weaning weight.

Table 3. Lenst-squares constants for breed of dam' for reproduction traits ${ }^{2}$

\begin{tabular}{lllllll}
\hline & No. obs. & $1.13 \mathrm{~N}$ & 1.513 & 1.521 & No. obs. & 1.556 \\
Total/overali mean & 11.4 & 6.37 & 6.51 & 5.40 & 104 & 5.06 \\
L.OC & 45 & $1.49^{\mathrm{a}}$ & 1.42 & 0.61 & 4.4 & 0.29 \\
N $/ W$ & 43 & $0.04^{\mathrm{b}}$ & 0.10 & 0.05 & 38 & -0.51 \\
CAL & 26 & $-1.53^{\mathrm{c}}$ & -1.52 & -0.66 & 22 & 0.22 \\
\hline
\end{tabular}

a.6. Constants within columns with different superscripts are significantly $(P<0.05)$ different.

'1.OC - Local, NZW - New Zealand White, CAL Californian.

$\therefore$ LBN = live birth number, LSB $=1$ itter size at birth, 1.521 (1.S56) - litter size at 21 days ( 56 days).

Table 4. Least-squares constants for breed of dam' for production traits ${ }^{2}$

\begin{tabular}{|c|c|c|c|c|c|c|c|c|c|c|c|}
\hline & $\begin{array}{l}\text { No. } \\
\text { obs. }\end{array}$ & $\begin{array}{l}\text { LWB } \\
(\mathrm{kg})\end{array}$ & $\begin{array}{l}\text { l.W21 } \\
(\mathrm{kg})\end{array}$ & $\begin{array}{l}\text { No. } \\
\text { obs. }\end{array}$ & $\begin{array}{l}\text { l.W56 } \\
(\mathrm{kg})\end{array}$ & $\begin{array}{l}\text { No. } \\
\text { obs. }\end{array}$ & $\begin{array}{l}\text { ADG21 } \\
\text { (g/d) }\end{array}$ & $\begin{array}{l}\text { No. } \\
\text { obs. }\end{array}$ & $\begin{array}{l}\text { ADCis6 } \\
(g / d)\end{array}$ & $\begin{array}{l}\text { No. } \\
\text { obs. }\end{array}$ & $\begin{array}{l}\text { IWW } \\
(g)\end{array}$ \\
\hline $\begin{array}{l}\text { Overall } \\
\text { mean }\end{array}$ & 114 & 0.354 & 1.210 & 97 & 3.839 & 112 & 7.9 & 94 & 15.8 & 442 & 755 \\
\hline LOC & 45 & $0.057^{\mathrm{s}}$ & 0.009 & 41 & -0.201 & 44 & $-4.5^{c}$ & 40 & 3.3 & 227 & $-138^{\prime \prime}$ \\
\hline NZW & 43 & $0.039^{\prime \prime}$ & -0.011 & 34 & 0.016 & 42 & $0.2^{b}$ & 32 & 2.3 & 135 & $68^{n}$ \\
\hline CAI. & 26 & $-0.096^{b}$ & 0.002 & 22 & 0.185 & 26 & $4.3^{\prime \prime}$ & 22 & -5.6 & 80 & $70^{n}$ \\
\hline
\end{tabular}

a.t. Constants within columns with different superscripts are significanly (P<0.05) differemt.

'Refer to Table 3.

$\therefore$ LWI3 Litter weight at birth, LW21 (LW56) * Litterweight it 21 days (at 56 days), A1)(22) Average ditil: growth rate from birtl to 21 days, $A D G 56 \cdots$ Average growth rate from 21 10 56 days. IWW Individual weaning weight. 


\section{Breed of dam}

LOC dams kindled litters with the highest live birth number (LBN), 1.49 above average (lable 3). Although the least- scuares constants were also highest for $1.0($ dams in LSB, IS.S21 and $1 . \$ 56$, differences between breeds of dam were not significamt ( $P>0.05)$. Least-scpuares constants for breed of dam for production traits (Table 4) show significant effects $(P<0.05)$ of the breeds on LWIB, $A D C 21$ and IWW. While I.OC dams were the best in I.WI3 (least-squares constant $57 \mathrm{~g}$ ), reflecting their highest performance in L.BN, their litters were the poorest in ADG21 (least-squares constant $-4.5 \mathrm{~g} / \mathrm{d}$ ) and IWW (least-squares constant $-138 \mathrm{~g}$ ). Dams of Californian breed excelled in ADG21 $(4.3 \mathrm{~g} / \mathrm{d}$ above the mean) and had IWW similar to that of N\%W does (70 g vs $68 \mathrm{~g}$ above the mean). However. they were the worst $(-96 \mathrm{~g}$ below average) in LWW The breeds of dam did not significantly $(B>0.05)$ influence the other production traits.

It is noteworthy that NZW dams were intermediate in performance of the dam breeds in all traits studied (both reproduction and production) including those in which significant differences did not exist, with the exception of L.\$56 and L.WV21. It would appear that L.OC dams had good prolificacy but poor mothering ability as reflected in IWW of their kits. NZW dams showed good prolificacy, mothering ability and growth potentials in their litters. Although the dam breeds did not differ in LW21, the observed differences in $\triangle D G 21$ may be considered a reflection of milk yich in the dams (lukefahre' (d) 1981). It could be deduced from the results that $\mathrm{C} A \mathrm{~L}$ dams lacked good prolificacy but had good mothering ability and growth potemials.

The superiority of NZW does over $C A \mathrm{~A}$. does in prolificacy has been established (Niedzwiadek. 1979; Rouvier, 1980; I,ukelahr et al.. 1983b). In agreement with the present study, Garcia et al. (1980) and Ledur et al. (1994) have shown that kits of CAL dams have higher growth potentials than those of NZW dams. Nevertheless, the ranking of NZW does as poorer milk producers compared with $C A L$ does (judged by $\wedge D(i 21)$ contradicts Lukefahr ef al. (1983b) who reported a highly significant superiority of
$0.91 \mathrm{~kg}$ of milk in NZW dams over CAL, dams in the early preweaning stage. $A$ possible explanation of the present result is that $\mathrm{CAl}$. does adapt better, and therefore show better mothering ability than NZW does in the tropics (l.edur ef al.,1994). The existence of reciprocal differences between IOC $\times$ NZW and NZW $x$ L.OC litlers in I.BN, I.SB, 1.556 and $1 \mathrm{WW}$ and belween N\%W $\times C A I$ and $C A I \times N Z W$ litlers in I.BN. LSB and IWW (Ngo Ndjon. 1997) would suggest differences in prolificacy: mothering ability and growth potentials between $1.0($ ) is NZW dams and NZW vs CAl, dams.

On the whole, breed of sire influenced only IWW whereas breed of dam effect was manifested in LIBN. LWWIB, ADC(21 and IWW. These findings are consistent with Lukefille er al.(1983a) who noted that maternal breed effects appeared to be much more important than sire breed effects in influencing preweaning liffer characters of rabbits.

\section{Conclusion}

The greatest cross advantages are expected in the mating CAL $x$ L.OC for prolificacy and mothering ability and L.OC $x$ CAl. for growth potentials to weaning. These results suggest that where the three breeds $1.0 C$. NZW and $C A L$ are available for crossbreding in Cameroon, the mating LOC $\times(\wedge)$, will produce the hest results in the traits considered.

\section{ACKNOWLEDGMENTS}

The authors are gratclial to the Director ofIRZV. Cameroon for permission to use the data from the Instiute for this study and for making arailable the statistical package used in part of the analysis. The cooperation of the entire stalf of the Institute is also acknowledged.

\section{REFERENCES}

Carregal, R. D. (1980). Evaluacion de la heterosis, de la capacidad de combinacion $y$ de los efectos maternos y reciprocos en concjos. (In Spanish). Proc. 2nd World Rabbit Congr. Barcelona. Spain.

Garcia, B., Blasco. A., Basclga, M. and Salvador. 
A. (1980). Analysis généticos de diversas caracteristicas reproductives en el conejo de carne. 2nd World Rabbit Congress. Barcelona 1: 202-212.

Harvey. W. R. (1990). User's guide for L.SMLMW and MIXMDI. Mixed model least-squares and maximum likelihood Computer program. Ohio State University. Columbus, Ohio, USA.

Ledur, M. C.. Carregal, R. D. and Bianchini Sobrinho, E. (1994). Evaluation of heterosis and maternal ability in rabbits during the growing period. Revista da sociedada Brasileira de Zootecnia 23 (2): 165-172.

Lukefahr, S. D., Hohenboken, W., Cheeke, P. R. and Patton, N. M. (1981). Milk production and litter growth traits in straightbred and crossbred rabbits. J. Appl. Rabbit Res.

$4(2): 35-40$.

Lukefahr, S., Hohenboken, W. D., Cheeke, P. R. and Patton, N. M. (1983a). Doe reproduction and preweaning litter performance of straightbred and crossbred rabbits. J. Anim. Sci. 57:1090-1099.

Lukefahr, S. D., Hohenboken, W., Cheeke, P. R. and Patton, N. M. (1983b). Characterization of straightbred and crossbred rabbits for milk production and associative traits. J. Anim. Sci. 57: 11001107.

Ngo Ndjon, M. (1997). Evaluation of crossbreeding exotic and local breeds of rabbits in Cameroon. M.Sc. project report, University of Nigeria, Nsukka.

Niedzwiadek, S. ( 1979). The performance of crossbred rabbits. (In Russian). Okrés. Wart. uzy. Kioli. mies. Roczniki Naukowe Zootecniki $6(1)$ : 145-153.

Partridge, G. G., Foley, S. and Corrigall, W. (1981). Reproductive performance in purebred and crossbred commercial rabbits. Anim. Prod. 32: 325-331.

Rouvier, R. (1973). Lapport des croisements dans L amelioration de L'Elevage du lapin de chair. (In lirench). Journées de
Recherches Avicoles et Cunicoles en France. December 12-14.

Rouvier. R. (1980). Génétique du lapin (O)ryctolagus cumiculus). 2nd World Rabbit Congress. Barcelona 1: 159-191.

Rouvier. R. (1981). Les travaux de recherche francais sur la sélection du lapin au cours des 10 dernieres annés (1970)-1980). ( R. Scances Acad. Agric. Fr. 67: 509-524. 